J. Clin. Chem. Clin. Biochem.

Vol. 21, 1983, pp. 35-37

\title{
Polyamine Excretion in the Urine of Cancer Patients
}

\author{
By D. Depierre, A. Jung \\ Centre d'Etude des Maladies Ostéo-articulaires,
}

J. Culebras and M. Roth

Laboratoire central de chimie clinique, Hôpital cantonal universitaire, Geneva

(Received January 18/July 26, 1982)

Summary: The polyamines putrescine, spermine, spermidine and cadaverine were determined in the urine of 56 cancer patients, most of whom suffered from breast or lung tumours. The excretion of spermine and putrescine was increased versus controls in a group of various.cancers with metastases. The excretion of spermine, spermidine and cadaverine was increased in lung cancer without metastases. Polyamines were analysed in the urine of six women with breast cancer, before and after mastectomy. The excretion of putrescine, spermine and cadaverine was lower 6 to 9 months after the operation than before.

\section{Ausscheidung von Polyaminen im Harn von Carcinom-Patienten}

Zusammenfassung: Die Polyamine Putrescin, Spermin, Spermidin und Cadaverin wurden im Harn von 56 Carcinom-Patienten (vor allem Patienten mit Mamma- oder Lungen-Carcinom) bestimmt. Die Ausscheidung von Spermin und Putrescin war in einer Gruppe verschiedener Carcinome mit Metastasen gegenüber Kontrollen erhöht. Bei Lungentumoren ohne Metastasen war die Ausscheidung von Spermin, Spermidin und Cadaverin erhöht. Polyamine wurden im Harn von 6 Patientinnen mit Mamma-Carcinom vor und nach Mastektomie bestimmt. Die Ausscheidung von Putrescin, Spermin und Cadaverin war 6-9 Monate nach der Operation geringer als zuvor.

\section{Introduction}

The polyamines spermine, spermidine and putrescine are strong cations of low molecular mass that appear to occur in all living cells, both prokaryotic and eukaryotic (1). They play an important role in cell growth and proliferation $(2,3)$. Their biosynthesis is linked to the intracellular synthesis of nucleic acids and proteins, and, indeed, polyamines are produced in particularly high amounts by rapidly growing tissues such as tumours and regenerating liver. This has stimulated the investigation of polyamines as possible biochemical markers of neoplasia. It has been shown indeed that cancer patients have increased concentrations of polyamines in plasma, urine, cerebrospinal fluid $(4,5)$ and erythrocytes $(6)$, and a relationship between polyamine concentration and the clinical status has been postulated.
There may be differences in the behaviour of the individual polyamines. Thus putrescine is almost absent from erythrocytes (6); under cancer chemotherapy, urinary spermidine has been shown to increase, probably as a consequence of cell kill (7). Another polyamine that occurs in urine is cadaverine, but this has received little attention so far (8).

In the present study polyamines were determined in the urine of a group of patients with advanced metastatic disease in comparison with normal controls and patients with operable tumours of breast and lung, in order to see whether significant differences could be observed between the three groups. Furthermore, the patients with non-metastatic tumours were operated and the urinary excretion of polyamines was determined before and after tumour removal. 
These investigations were performed with a sensitive and specific technique, which allowed the determination not only of putrescine, spermidine and spermine, but also cadaverine, a hitherto relatively neglected polyamine.

\section{Materials and Methods}

\section{Procedure}

Urinary polyamines were determined by ion-exchange chromatography followed by fluorimetric detection of the reaction product with $o$-phthalaldehyde, according to the method of Culebras Poza et al (9). Reference intervals in non-cancer patients suffering from benign diseases other than hepatic or renal $(\bar{x} \pm 2 s)$ expressed as micromoles polyamines per mole creatinine were: putrescine $1934 \pm 1494$; spermidine $588 \pm 249$; spermine $407 \pm 181$, and cadaverine $87 \pm 101$ (9). Creatinine was determined by continuous flow analysis according to Chasson et al (10).

All analyses including those for the establishment of reference. values were done on the first urine voided in the morning. Urine samples were collected over a few crystals of thymol, acidified with hydrochloric acid and stored at $-20^{\circ} \mathrm{C}$. In a previous report (9) we had shown that the morning urine provides essentially the same results as a $24 \mathrm{~h}$ collection, if the polyamines are expressed relative to the creatinine concentration.

Statistical analysis was done with the $\mathrm{t}$ test of Student.

\section{Patients}

Two groups of patients were studied. The first consisted of 24 cancer patients (13 men and 11 women), most of whom suffered from breast or lung tumours with multiple metastases (bone, liver, lung, etc.). The age range was between 43 and 87 years. Polyamines were determined during their stay in the hospital. The other group was composed of non-metastatic patients admitted for operation, of whom 21 , aged from 40 to 88 years, had breast tumours, and 11, aged from 20 to 69 years, had lung tumours. In this group, polyamines were determined 1 to 3 days before and 8 to 10 days after operation. For 6 of the patients with breast cancer, a follow-up was possible, with some determinations being made up to 9 months after mastectomy.

\section{Results}

Table 1 shows the polyamine excretion in urine in comparison with controls. In breast cancer without metastases, the mean values of spermidine, spermine and cadaverine were higher than controls, but the difference was not significant. In lung cancer without metastases, the same polyamines were significantly elevated. In cancers of various types with metạstäses, a significant increase of putrescine and spermine was observed.

Six cases of breast cançer were followed for a long period beginning just before mastectomy. The results are shown in table 2. There was a significant decrease of putrescine, spermine and cadaverine between the moment preceding operation and the period within 6-9 months thereafter. The mean concentrations of putrescine, spermine and cadaverine were increased 8-10 days after operation, but the increase was not significant.

\section{Discussion}

In accordance with the findings of other authors this study shows that individuals with advanced cancer generally have an increased excretion of polyamimines in their urine. We observed this not only for the usually described polyamines putrescine, spermine and spermidine, but also, in the case of cancers without metastases, for cadaverine.

Tab. 1. Polyamine excretion in urine expressed as polyamine/creatinine ratio ( $\mathrm{mmol} / \mathrm{mol})$.

Mean \pm SED (Standard error of the mean), with range in parenthesis. $p$ and N. S. (non significant) refer to the difference with controls.

\begin{tabular}{|c|c|c|c|c|c|c|}
\hline Group & $\mathbf{N}$ & Putrescine & Spermidine & Spermine & $\begin{array}{l}\text { Total } \\
\text { putrescine }+ \\
\text { spermidine }+ \\
\text { spermine }\end{array}$ & Cadaverine \\
\hline Controls & 13 & $\begin{array}{c}1.81 \pm 0.17 \\
(0.71-2.46)\end{array}$ & $\begin{array}{c}0.58 \pm 0.03 \\
(0.26-0.75)\end{array}$ & $\begin{array}{c}0.20 \pm 0.02 \\
(0.07-0.34)\end{array}$ & $\begin{array}{c}2.60 \pm 0.18 \\
(1.59-3.39)\end{array}$ & $\begin{array}{l}0.09 \pm 0.01 \\
(0.0-1.15)\end{array}$ \\
\hline $\begin{array}{l}\text { Breast cancer } \\
\text { (without metastases) }\end{array}$ & 21 & $\begin{array}{c}1.60 \pm 0.18 \\
(0.68-4.33) \\
\text { N.S. }\end{array}$ & $\begin{array}{l}1.60 \pm 0.65 \\
(0.36-10.54) \\
\text { N.S. }\end{array}$ & $\begin{array}{c}0.57 \pm 0.17 \\
(0.05-3.26) \\
\text { N.S. }\end{array}$ & $\begin{array}{c}3.80 \pm 0.72 \\
(1.45-13.67) \\
\text { N.S. }\end{array}$ & $\begin{array}{c}0.87 \pm 0.36 \\
(0.03-7.78) \\
\text { N.S. }\end{array}$ \\
\hline $\begin{array}{l}\text { Lung cancer } \\
\text { (without metastases) }\end{array}$ & 11 & $\begin{array}{c}3.67 \pm 1.34 \\
(1.45-16.96) \\
\text { N.S. }\end{array}$ & $\begin{array}{c}1.35 \pm 0.31 \\
(0.47-4.20) \\
p<0.05\end{array}$ & $\begin{array}{c}0.45 \pm 0.09 \\
(0.13-1.11) \\
p<0.01\end{array}$ & $\begin{array}{c}3.91 \pm 0.47 \\
(2.08-19.06) \\
p<0.05\end{array}$ & $\begin{aligned} 0.29 & \pm 0.10 \\
(0.07 & -1.24) \\
p & <0.05\end{aligned}$ \\
\hline $\begin{array}{l}\text { Cancers } \\
\text { with metastases }\end{array}$ & 24 & $\begin{array}{c}4.15 \pm 0.54 \\
(0.84-11.28) \\
p<0.01\end{array}$ & $\begin{array}{c}4.55 \pm 1.82 \\
(0.05-42.63) \\
\text { N.S. }\end{array}$ & $\begin{array}{c}0.45 \pm 0.07 \\
(0.12-3.26) \\
p<0.01\end{array}$ & $\begin{array}{c}9.16 \pm 1.84 \\
(1.22-44.53) \\
p<0.05\end{array}$ & $\begin{array}{c}0.85 \pm 0.45 \\
(0.02-10.36) \\
\quad \text { N.S. }\end{array}$ \\
\hline
\end{tabular}


Tab. 2. Polyamine excretion in urine expressed as polyamine/creatinine ratio $(\mathrm{mmol} / \mathrm{mol})$ in six patients with breast cancer before and after operation. Values expressed as mean \pm SED.

\begin{tabular}{|c|c|c|c|c|c|}
\hline Status & Putrescine & Spermidine & Spermine & $\begin{array}{l}\text { Total } \\
\text { putrescine }+ \\
\text { spermidine }+ \\
\text { spermine }\end{array}$ & Cadaverine \\
\hline before operation & $\begin{array}{r}1.65 \\
\pm 0.18\end{array}$ & $\begin{array}{r}2.20 \\
\pm 1.63\end{array}$ & $\begin{array}{r}0.35 \\
\pm 0.09\end{array}$ & $\begin{array}{r}4.20 \\
\pm 1.58\end{array}$ & $\begin{array}{r}0.42 \\
\pm 0.07\end{array}$ \\
\hline 10 days after & $\begin{array}{r}2.00 \\
\pm 0.23\end{array}$ & $\begin{array}{r}0.94 \\
\pm 0.14\end{array}$ & $\begin{array}{r}0.45 \\
\pm 0.10\end{array}$ & $\begin{array}{r}3.39 \\
\pm 0.27\end{array}$ & $\begin{array}{r}0.49 \\
\pm 0.18\end{array}$ \\
\hline 6-9 months later & $\begin{array}{r}1.12 \\
\pm 0.11\end{array}$ & $\begin{array}{r}0.70 \\
\pm 0.21\end{array}$ & $\begin{array}{r}0.15 \\
\pm 0.05\end{array}$ & $\begin{array}{r}1.97 \\
\pm 0.23\end{array}$ & $\begin{array}{r}0.12 \\
\pm 0.05\end{array}$ \\
\hline
\end{tabular}

These changes, however, are not of such consistency as to allow a diagnosis to be made in individual cases. The values of each group scatter within wide limits, and it is hardly possible to draw conclusions from the differences observed between cancers with or without metastases.

A more promising use of polyamine assay is likely to be the follow-up of patients before, during and after treatment. Thus, we have found that the surgical removal of a malignant breast tumour results in a decrease of putrescine, spermine and cadaverine which is significant 6-9 months after surgery. Measurement of polyamines 8-10 days after surgery, on the other hand, does not reveal such a distinct change, as many patients then excrete more polyamines than before. It seems that within this early post-operative period, a decrease of polyamines due to tumour removal may be outweighed by an increase due to regenerating tissue.

In conclusion, the excretion of polyamines in urine does not seem to provide a reliable index of tumour growth or-size, and could at best be valuable in a multivariate analysis as suggested by Woo et al (11).

The most useful application of polyamine analysis might well be the serial determination before and during an extended period after surgery. If such longitudinal studies allow the detection of a relapse of the cancer process before it becomes clinically detectable, this would be an interesting advance in the long-term management of cancer patients.

\section{References}

1. Tabor, H. A. \& Tabor, C. (1968) Adv. Enzymol. 36, 203-268.

2. Pösö, H. \& Raina, A. (1978) Biochim. Biophys. Acta 473, 241-293.

3. Heby, O., Marton, L. M., Wilson, C. B. \& Martinez, H. M. (1975) FEBS Lett. 50, 1-4.

4. Marton, L., Vaughn, J., Hawk, I., Levy, C. K. \& Russell, D. (1973) in Polyamines in normal and neoplastic growth, pp. 367-372 (Russell, D., ed.) Raven Press, New York.

5. Nishioka, K. \& Romsdahl, M. M. (1974) Clin. Chim. Acta $57,155-164$.

6. Uehara, N., Shirakawa, S., Uchino, H. \& Saeki, Y. (1980) Cancer 45, 108-111.

7. Durie, B. G. M., Salmon, S. E. \& Russell, D. (1977) Cancer Research 37, 214-221.

8. Henningsson, S., Persson, L. \& Rosengren, E. (1976) Acta Physiol. Scand. 98, 445-449.

9. Culebras Poza, J. M., Depierre, D. \& Roth, M. (1979) Anal. Letters 12 (B 1) 37-45.

10. Chasson, A. L., Grady, H. T. \& Stanley, M. A. (1961) Am. J. Clin. Pathol. 35, 83.

11. Woo, K. B., Waalkes, T. P., Ahmann, D. L., Tormey, D. C., Gehrke, C. W. \& Oliverio, U. T. (1978) Cancer 41, 1685-1703.

PD. Dr. M. Roth

Laboratoire central de chimie clinique

Hôpital cantonal universitaire

CH-1211 Genf 4 
